\title{
Avian diversity of Vadakkechira area, a green lung of Thrissur
}

\author{
Kezia Kuruvilla \\ (Dept.of Zoology, Vimala College, Thrissur, India)
}

\begin{abstract}
Urbanization and loss of natural habitat has resulted in cities being identified as ecosystems capable of sustaining biotic communities and diversity. This study measured bird species diversity at Vadakkechira pond and surrounding areas during the period 2002-2009. This habitat is situated right in the heart of the city of Thrissur which is renowned for its historic importance and cultural extravaganzas. Data was collected by line transect method and point transect method. Birds of 29 different species were recorded. Shannon-Weiner Diversity Index and Simpson's Diversity Index were calculated. Dominant species of the area were identified and their population over the years was studied. The abundance and diversity of avian species in a specific habitat could serve as a useful barometer of its ecological status.
\end{abstract}

Keywords: Avifauna, Bird census, Diversity, Habitat, Vadakkechira

\section{Introduction}

Urbanization endangers species by directly replacing native habitats with development on the urbanrural fringe, and depleting resources in the surrounding areas to support urban economies [1]. Urban areas are expected to grow substantially in coming years. By 2030, the percentage of the world's population living in urban areas is projected to increase from the current $49 \%$ to approximately $61 \%$ [2].To assess the resulting habitat changes and degradation, birds are often used as a biological model, as they are good ecological indicators and are easily observable [3].

Tropical wetlands form the habitat for a wide variety of plants and animals. They also play an important role as habitat for migratory water birds and as centers of biotic networking. The surface water bodies and green patches within the city limits are progressively being subjected to stress due to anthropogenic activities which drastically influence the bird population seen around these habitats. Ecological studies on the composition and structure of biological communities are an effective way of probing into the interactions between the species that comprise them, and an ideal method of identifying the regional biodiversity. The avian diversity of a fulcral point in Thrissur city forms the subject of focus for this study.

\section{Study Area}

Sakthan Thampuran palace or the Vadakkechira Kovialakam is a figurative testimony of Kerala Architecture blended with Dutch architecture. The palace with its gardens, huge trees and serpent grove is situated in a 6.5 acre plot in the centre of Thrissur city of Kerala, India. Vadakkechira pond built by Sakthan Thampuran (1751-1805), the architect of modern Thrissur, for water management and irrigation purposes is seen adjacent to the palace ground. The 2.5-acre Vadakkechira pond is one of the famous landmarks of Thrissur.

Thrissur is located in the geographical coordinates of $10^{0} 32^{\prime} \mathrm{N}$ and $76^{\circ} 15^{\prime} \mathrm{E}$. The maximum average temperature of the city in summer season is $36^{\circ} \mathrm{C}$ while the minimum temperature recorded is $22.5^{\circ} \mathrm{C}$. The winter season records a maximum average of $32.3^{\circ} \mathrm{C}$ and a minimum average of $20^{\circ} \mathrm{C}$. Heavy rainfall is received during the two distinct rainy seasons South-West monsoon (June to September) and North-East monsoon (October to November). Maximum precipitation is in the months of June-July with an average annual rainfall record of $3200 \mathrm{~mm}$. January and February are the driest months. March, April and May months experience occasional rains.

\section{Methods}

The sampling locations included the large pond and the greenery area adjacent to it belonging to the Sakthan Thampuran palace. Study was mainly based on line transect method [4] and point transect method [5]. T ot a l c o un t method was also employed for estimating bird population [6] in the water body. Data was collected during the time period 2002 to 2009. Birds were identified and classified according to Ali and Ripley[7][8].The common and scientific names are after Manakadan and Pittie [9] and taxonomy according to Inskipp et al [10] and Ripley [11]. The time of observation was between 0600 hrs to $0900 \mathrm{hrs}$ and $1500 \mathrm{hrs}$ to $1800 \mathrm{hrs}$. Observations were made during the quarters of 1)March-May 2)June-August 3)September-November and 4)December- February between the years of 2002-2009. An average of three visits was made during each period with a minimum of 10 days interval. 
Species richness, species composition and species evenness of the study site were calculated from the census data and field observations. The number of species recorded was taken as species richness, which is a measure of diversity. Species richness indices like Margalef Index (R1) and Menhinick Index (R2) were calculated. Species diversity was assessed using Shannon-Weiner Index and Simpson Index. Evenness is a measure of the relative abundance of different species. Dominance index was also calculated.

Frequency of occurrence and comparative abundance was found out as described elsewhere [12]. The bird species found more than 1000 individuals per day in the locality were termed as very abundant, those between 201 to 1000 individuals were termed as abundant, and those found between 51 to 200 individuals were termed as very common, whereas those found between 21 to 50 individuals were considered as common species. Bird species, having population 7 to 20 individuals per day were termed as fairly common, whereas those observed between one to six were named as uncommon. Birds with one to six individuals per season were described as rare. Bird species having infrequent occurrence were termed as very rare species.

\section{Results}

The region under study homes many avian species, both resident and migratory ones. The study area situated right in the heart of the city with large number of visitors throughout the year displayed appreciable amount of species diversity. A total of 29 species of birds belonging to 23 different families were identified and surveyed. Every community is highly specific in its structure which is dependent on the species representing the area. Species evenness of the area was calculated as 0.75 . The number of species found in a community and the species evenness is an indicator of the species diversity of the ecosystem. Shannon -Weiner Index was found to be 2.52 .

The birds identified in the area were mostly residents. 22 species belonged to this group and six species were local migrants. The only long distance migrant observed in the study area was Anas acuta, commonly called the Northern pintail. Local occurrence status of the avian fauna showed $31 \%$ of birds to be very common, $24.1 \%$ to be common, $17.2 \%$ to be fairly common and $20.7 \%$ to be uncommon. The very common species identified in the area include Acridotheres tristis, Columba livia, Corvus splendens, Copsychus saularis, Cinnyris asiaticus, Lonchura punctulata, Dicrurus macrocercus, Psittacula krameri and Turdoides striata.

Many of the water birds identified showed seasonal entry and cleared off after the season. The Vadakkechira area and palace was found to be abuzz with water birds from November-February. The most dominant species according to their population size identified was Dendrocygna javanica which came in flocks during the November- December months. The arrival of these birds is looked forward to by the city dwellers and attracts a lot of visitors to the area. These birds appeared in large numbers only during the season from November-February each year. The dominant species found throughout the year included Acridotheres tristis, Corvus splendens and Turdoides striata.

The study over the period of 2002-2009 has shown a downward trend in the total number of birds of the locality. This trend was very obvious in the case of species like Anhinga melanogaster, Ardeola grayii, Dendrocygna javanica, Anas acuta, Amaurornis phoenicurus, Columba livia and Turdoides striata which displayed a reduction in their population. On the other hand Bubulcus ibis population is seen to be on the rise. Seasonal variation was a factor which influenced the bird population. Least number of birds was spotted during the June-August time. This coincided with the heavy rains of South-West monsoon which is locally called as 'Kalavarsham'. Birds were abundant from September to February.

\section{Discussion}

Birds are said to be bio-indicators of an ecosystem. They represent the prevailing ecological conditions of the area and act as good markers to the changing scenario. The area under study is a green patch right in the middle of the city, often forming a refuge for the locals as well as the tourist from the bustle of the city. The District Tourism Promotion Council undertook the beautification project of Vadakkechira which was completed in 2006 with the construction of seats, padippuras, fountains, bird watching counter, and a gallery. These modifications attracted more visitors to the area. Our study showed a drastic reduction in the bird population after these construction activities. Anhinga melanogaster, Ardeola grayii, Dendrocygna javanica, Anas acuta, Amaurornis phoenicurus, Columba livia and Turdoides striata showed reduction in their number during the period of study. All the anthropogenic activities in this area were definitely an encroachment into the calmness and solitude of nature which has ultimately taken its toll on the bird population.

The Shannon-Weiner Diversity Index which specifies the comparative occurrence of species can be used to associate species abundance and relative richness amongst species [13][14]. In our study Shannon Weiner Index was found to be 2.52 . The species richness and composition serve as an important parameter for the stability and functioning of the ecosystem. 
Despite the significant destruction and degradation of habitats, urban areas have the capacity to support a wide diversity of vertebrate and invertebrate fauna species, perhaps due to the range of diverse natural and artificial habitat niches and conditions that occur in urban areas [15][16][17]. Green spaces in the form of parks, reserves, private gardens, wetland, lakes etc. in the urban areas contribute towards the formation of diversified ecosystems [18][19], and the heterogeneity of natural environment is one of the most important factor that contribute to an increase in biodiversity [20].

Urban habitats favour species that are better able to adapt to heavy traffic, pollution artificial light, and intrusion by man into their habitat [21]. The increase in the number of Bubulcus ibis is a clear indication of its adaptation to human dwellings. Large numbers of these birds are seen in the cities particularly around the waste dumping areas. As more of the natural habitats are disappearing, urban birds will comprise the larger cross section of our avifauna. These avian fauna can truly act as good biotic indicators in the maintenance and management of the ecosystems.

\section{Conclusion}

With each advancing year, a greater proportion of people is moving out into cities. As new cities emerge, and older ones grow, greater importance should be given to thoughtful planning and designing of green infra structure. Moreover, the existing parks and public spaces should be treated with utmost care to conserve its biodiversity which forms the ecological frame work for environmental and economic sustainability. Vadakkechira pond and the neighboring areas provide a breathing area for the city dwellers of Thrissur. Dendrocygna javanica which comes in flocks during the November- December months is a visual treat to them. The various species of birds and the soothing experience of the study area is something that needs to be preserved.

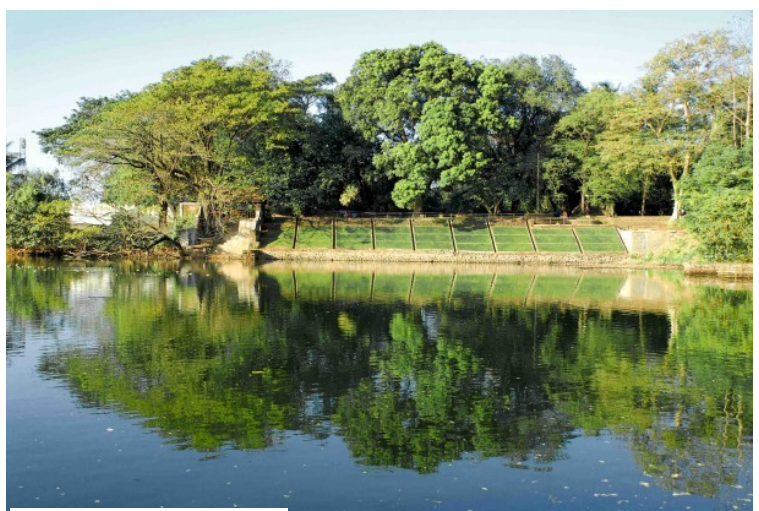

Fig. 1. View of the Vadakkechira and nearby area

Table 1. List of birds recorded from Vadakkechira area

\begin{tabular}{|c|c|c|c|c|}
\hline Family & Scientific name & Common name & $\begin{array}{l}\text { Abun } \\
\text { dance }\end{array}$ & $\begin{array}{l}\text { Stat } \\
\text { us }\end{array}$ \\
\hline Family: Podicipedidae & Tachybaptus ruficollis (Pallas, 1764) & Little Grebe & $\mathrm{U}$ & $\mathrm{R}$ \\
\hline Family: & Phalacrocorax carbo (Linnaeus, 1758) & Great Cormorant & $\mathrm{U}$ & LM \\
\hline Phalacrocoracidae & Phalacrocorax niger (Vieillot, 1817) & Little Cormorant & $\mathrm{U}$ & $\mathrm{R}$ \\
\hline Family: Anhingidae & Anhinga melanogaster (Pennant, 1769 ) & Darter & $\mathrm{C}$ & LM \\
\hline \multirow[t]{3}{*}{ Family: Ardeidae } & Ardeola grayii (Sykes, 1832) & Indian Pond-Heron & $\mathrm{C}$ & $\mathrm{R}$ \\
\hline & Bubulcus ibis (Linnaeus, 1758) & Cattle Egret & $\mathrm{C}$ & $\mathrm{R}$ \\
\hline & Egretta garzetta (Latham, 1790) & Little Egret & $\mathrm{U}$ & $\mathrm{R}$ \\
\hline Family: & Threskiornis melanocephalus & Asian white Ibis & $\mathrm{R}$ & LM \\
\hline Threskiomithidae & (Linnaeus, 1766) & & & \\
\hline \multirow[t]{2}{*}{ Family: Anatidae } & Dendrocygna javanica (Horsfield,, 1821) & $\begin{array}{l}\text { Lesser Whistling- } \\
\text { Duck }\end{array}$ & A & LM \\
\hline & Anas acuta (Linnaeus, 1758) & Northern pintail & $\mathrm{C}$ & M \\
\hline Family: Rallidae & Amaurornis phoenicurus (Pennant, 1769) & $\begin{array}{c}\text { White breasted } \\
\text { Waterhen }\end{array}$ & $\mathrm{C}$ & $\mathrm{R}$ \\
\hline Family: Accipitridae & Haliastur indus (Boddaert, 1783) & Brahminy Kite & $\mathrm{U}$ & $\mathrm{R}$ \\
\hline Family: Columbidae & Columba livia (Gmelin, 1789) & Blue Rock Pigeon & $\mathrm{VC}$ & $\mathrm{R}$ \\
\hline \multirow{2}{*}{ Family: Cuculidae } & Eudynamys scolopaceus (Linnaeus, 1758) & Asian Koel & $\mathrm{FC}$ & $\mathrm{R}$ \\
\hline & Centropus sinensis (Stephens, 1815) & Greater Coucal & $\mathrm{FC}$ & $\mathrm{R}$ \\
\hline Family: Alcedinidae & Alcedo atthis (Linnaeus, 1758) & $\begin{array}{l}\text { Small Blue } \\
\text { Kingfisher }\end{array}$ & $\mathrm{FC}$ & $\mathrm{R}$ \\
\hline Family: Oriolidae & Oriolus xanthornus (Linnaeus, 1758) & Black-hooded & $\mathrm{U}$ & $\mathrm{R}$ \\
\hline
\end{tabular}




\begin{tabular}{|c|c|c|c|c|}
\hline & & Oriole & & \\
\hline Family: Sturnidae & Acridotheres tristis (Linnaeus, 1766) & Common Myna & VC & $\mathrm{R}$ \\
\hline Family: Corvidae & Dendrocitta vagabunda (Latham, 1790) & Rufous Treepie & $\mathrm{C}$ & $\mathrm{R}$ \\
\hline & Corvus splendens (Vieillot, 1817) & House Crow & $\mathrm{VC}$ & $\mathrm{R}$ \\
\hline Family: Pycnonotidae & Pycnonotus jocosus (Linnaeus, 1758) & $\begin{array}{l}\text { Red-whiskered } \\
\text { Bulbul }\end{array}$ & $\mathrm{C}$ & LM \\
\hline Family: Muscicapidae & Copsychus saularis (Linnaeus, 1758) & $\begin{array}{l}\text { Oriental magpie } \\
\text { robin }\end{array}$ & $\mathrm{VC}$ & $\mathrm{R}$ \\
\hline Family: Nectariniidae & Cinnyris asiaticus (Latham, 1790) & Purple sunbird & $\mathrm{VC}$ & $\mathrm{R}$ \\
\hline Family: Estrildidae & Lonchura punctulata (Linnaeus, 1758) & Munia & $\mathrm{VC}$ & $\mathrm{R}$ \\
\hline Family: Dicruridae & Dicrurus macrocercus (Vieillot, 1817) & Black drongo & $\mathrm{VC}$ & LM \\
\hline Family: Psittacidae & Psittacula krameri (Scopoli, 1769) & $\begin{array}{l}\text { Rose Ringed } \\
\text { Parakeet }\end{array}$ & $\mathrm{VC}$ & $\mathrm{R}$ \\
\hline Family: Tytonidae & Tyto alba (Scopoli, 1769) & Barn owl & FC & $\mathrm{R}$ \\
\hline Family: Picidae & Dinopium benghalense (Linnaeus, 1758) & $\begin{array}{l}\text { Black-rumped } \\
\text { flameback wood } \\
\text { pecker }\end{array}$ & FC & $\mathrm{R}$ \\
\hline Family: Leiothrichidae & Turdoides striata (Dumont, 1823) & Jungle Babbler & $\mathrm{VC}$ & $\mathrm{R}$ \\
\hline
\end{tabular}

A -Abundant, VC -Very Common, C-Common, FC -Fairly Common, U -Uncommon, R -Rare $\mathrm{R}$-Resident, LM - Local Movement, M -Migrant

Table 2. Bird population of Vadakkechira area

\begin{tabular}{|c|c|c|c|c|c|}
\hline Bird & 2002- 2003 & 2004- 2005 & 2006-2007 & 2008-2009 & Total \\
\hline Tachybaptus ruficollis & 16 & - & 26 & - & 42 \\
\hline Phalacrocorax carbo & 37 & 36 & 12 & 8 & 93 \\
\hline Phalacrocorax niger & 32 & 16 & - & - & 48 \\
\hline Anhinga melanogaster & 279 & 313 & 69 & 47 & 708 \\
\hline Ardeola grayii & 162 & 143 & 111 & 70 & 486 \\
\hline Bubulcus ibis & 76 & 97 & 167 & 278 & 618 \\
\hline Egretta garzetta & 76 & - & 37 & - & 113 \\
\hline Threskiornis melanocephalus & - & 4 & - & - & 4 \\
\hline Dendrocygna javanica & 3750 & 4222 & 3254 & 1437 & 12663 \\
\hline Anas acuta & 235 & 298 & 138 & 86 & 757 \\
\hline Amaurornis phoenicurus & 230 & 287 & 205 & 156 & 878 \\
\hline Haliastur indus & 46 & - & - & 18 & 64 \\
\hline Columba livia & 430 & 367 & 254 & 159 & 1210 \\
\hline Eudynamys scolopaceus & 46 & 78 & 39 & 53 & 216 \\
\hline Centropus sinensis & 62 & 59 & 50 & 70 & 241 \\
\hline Alcedo atthis & 75 & 89 & 48 & 69 & 281 \\
\hline Oriolus xanthornus & 18 & 8 & 5 & - & 31 \\
\hline Acridotheres tristis & 598 & 476 & 494 & 512 & 2080 \\
\hline Dendrocitta vagabunda & 154 & 137 & 78 & 254 & 623 \\
\hline Corvus splendens & 670 & 549 & 476 & 576 & 2271 \\
\hline Pycnonotus jocosus & 287 & 367 & 143 & 256 & 1053 \\
\hline Copsychus saularis & 476 & 489 & 378 & 578 & 1921 \\
\hline Cinnyris asiaticus & 587 & 333 & 256 & 547 & 1723 \\
\hline Lonchura punctulata & 356 & 265 & 478 & 437 & 1536 \\
\hline Dicrurus macrocercus & 487 & 256 & 278 & 367 & 1388 \\
\hline Psittacula krameri & 256 & 457 & 378 & 352 & 1443 \\
\hline Tyto alba & 103 & 68 & 84 & 76 & 331 \\
\hline Dinopium benghalense & 190 & 74 & 34 & 94 & 392 \\
\hline Turdoides striata & 859 & 685 & 586 & 438 & 2568 \\
\hline Total & 10593 & 10173 & 8078 & 6938 & 35782 \\
\hline
\end{tabular}

Table 3. Diversity of avian fauna of Vadakkechira area

\begin{tabular}{|c|l|}
\hline Richness index & 2.67 \\
Margalef & 0.153 \\
Menhinick & \\
\hline Diversity index & 2.523 \\
Shannon-Weiner Index & 0.305 \\
Simpson Index & 0.75 \\
\hline Species Evenness & 0.695 \\
\hline Dominance Index &
\end{tabular}




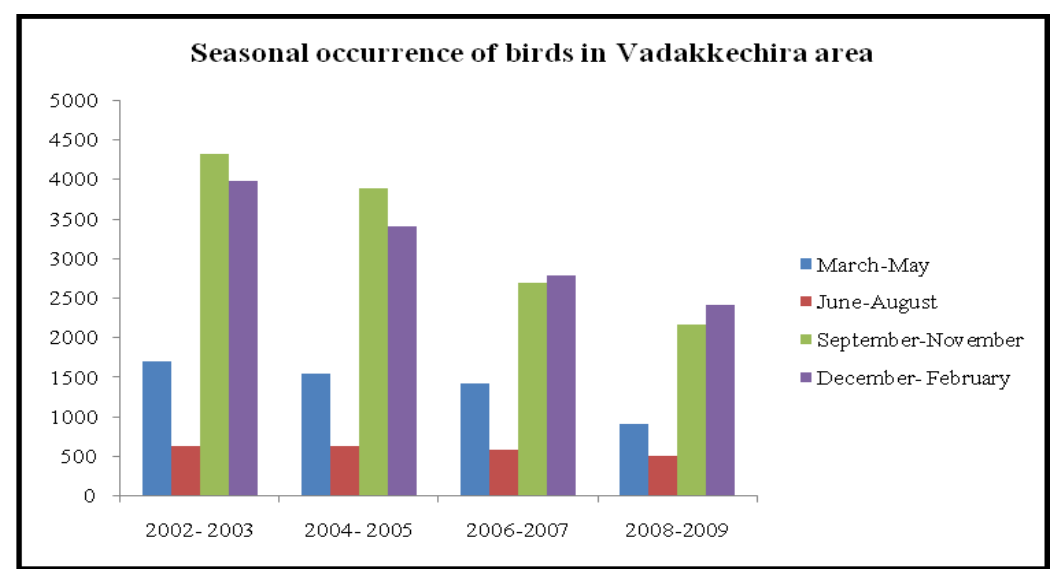

\section{Occurrence status of avian fauna in Vadakkechira area}

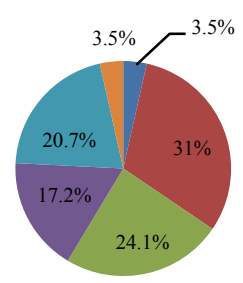

- Abundant

- Very Common

Common

- Fairly common

- Uncommon

Rare

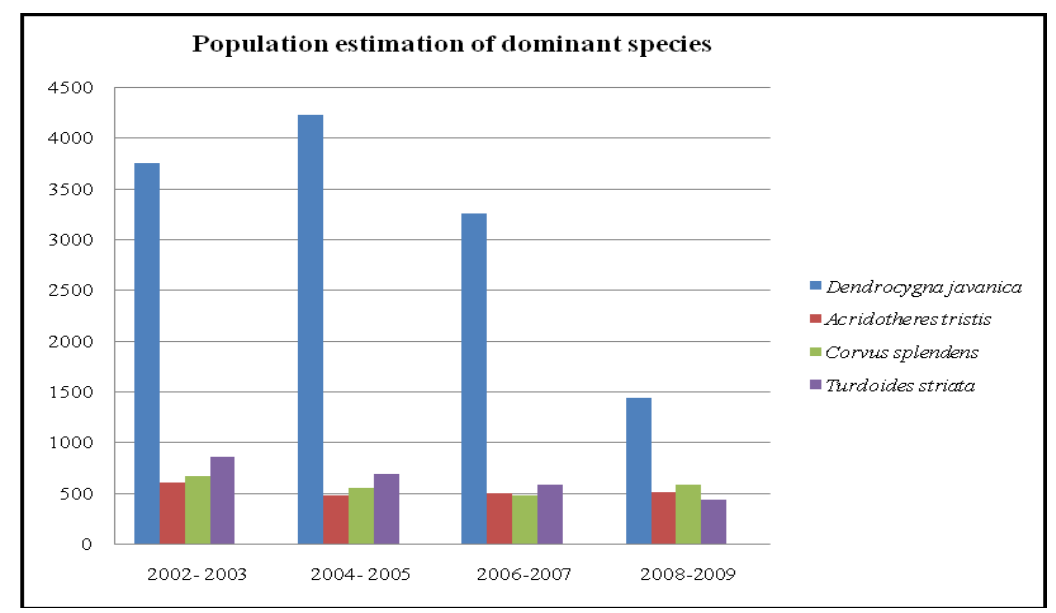

References

[1]. B.Czech, P.R.Krausman, and P.K.Devers, Economic associations among causes of species endangerment in the United States, Bioscience, 50, 2000, 593-601.

[2]. United Nations, Department of Economic and Social Affairs, population division, World urbanization prospects 2004.

[3]. P.Clergeau, G.Mennechez, A. Sauvage and A. Lemoine, Human perception and appreciation of birds: A motivation for wildlife conservation in urban environments of France, in J.M.Marzluff, R.Bowman and R. Donnelly (Ed.), Avian ecology in an urbanizing world, (Norwell, Kluwer Academic publisher, 2001) 69-88.

[4]. J.B.Sale, and K.Berkmuller, Manual of wildlife techniques for India. Field document No.11 (FAO, United Nations, Dhera Dun, India, 1988)

[5]. J.Altman, Observational study of behaviour, sampling methods, Behaviour, 49, 1974, 227-267.

[6]. J..Howes, and D.Bakewell, Shorebird studies manual (Asian Wetland Bureau Publ. No. 55, Kuala Lumpur, Malaysia, 1989).

[7]. S.Ali, and S.D.Ripley, A Pictorial Guide to the Birds of the Indian Subcontinent (Oxford Univ. Press, Oxford, 1983).

[8]. S.Ali, and S.D.Ripley, Handbook of the Birds of the India and Pakistan, Vol. 5 (Oxford Univ. Press, Oxford, 1986).

[9]. R.Manakadan, and A..Pittie, Standardised common and scientific names of the birds of the Indian subcontinent, Buceros, 6 (1), 2001, 1-37.

[10]. T.Inskipp, N.Lindsey and W.Duckworth, An annotated checklist of the birds of the oriental region (Oriental Bird Club, UK, 1996).

[11]. Ripley, and S Dillon, Indian Birds VII, Postilla, 35, 1958, 1-12.

[12]. J.Bull, Birds of New York State (Doubleday Natural History Press: Garden City, NY, 1974).

[13]. R.H.Whittaker, Evolution of species diversity on land communities, Evolutionary Biology, 10, 1977, 1-67. 
[14]. M.G.Barbour, J.H.Burk, W.D.Pitts, F.S.Gilliam, and M. W. Schwartz, Terrestrial Plant Ecology-third edition (Benjarmin/Cummings: Menlo Park, California, 1998).

[15]. J.Niemelä, Ecology and urban planning, Biodivers. Conserv, 8, 1999, 119-131.

[16]. J.Niemelä, Is there a need for a theory of urban ecology?, Urban Ecosysem, 3, 1999, 57-65.

[17]. J.P.Collins, A.P.Kinzig, N.B.Grimm, W.F.Fagan, D.Hope, J.Wu and E.T.Borer, A new urban ecology, American Scientist 88, 2000, 416-425.

[18]. V.Schaefer, Urban biodiversity, in L. E. Harding, and E. McCullum (Ed.), Biodiversity in British Columbia, (Environment Canada, Canadian Wildlife Service, Vancouver, British Columbia, Canada, 1994) 307-318.

[19]. M.M.Argel-de-Oliveira, Aves e vegetação em um bairro residencial da cidade de São Paulo, Brasil, Revta bras. Zool., 12 (1), 1995 , 81-92.

[20]. J.R.Karr, Seasonality, resource availability, and community diversity in tropical bird communities, Am. Nat., 110, 1976, 973-994.

[21]. http://web.stanford.edu/group/stanfordbirds/text/essays/Urban_Birds.html 